\title{
Penentuan Serotipe Virus Dengue dan Gambaran Manifestasi Klinis serta Hematologi Rutin pada Infeksi Virus Dengue
}

\author{
Basti Andriyoko, Ida Parwati, Anna Tjandrawati, Leni Lismayanti \\ Departemen Patologi Klinik Fakultas Kedokteran Universitas Padjadjaran \\ Rumah Sakit Dr. Hasan Sadikin
}

\begin{abstract}
Abstrak
Setiap serotipe virus dengue dapat menimbulkan manifestasi klinis mulai dari demam dengue (DD) sampai demam berdarah dengue (DBD) dan sindrom syok dengue (SSD). Sulit untuk menilai karakteristik klinis dan hasil hematologi yang khas untuk setiap serotipe. Tujuan penelitian ini untuk menentukan serotipe virus dengue dan gambaran manifestasi klinis DD, DBD, SSD serta hasil pemeriksaan hematologi rutin yaitu hemoglobin, hematokrit, leukosit, dan trombosit pada setiap serotipe virus dengue. Penelitian dilakukan di Rumah Sakit Dr. Hasan Sadikin Bandung sejak Maret 2010 sampai Juli 2011. Subjek penelitian adalah penderita infeksi dengue usia $\geq 14$ tahun dengan riwayat demam $\leq 5$ hari. Sampel darah diambil untuk penentuan serotipe dengue dengan teknik reverse transcription polymerase chain reaction (RT-PCR) dilanjutkan dengan seminested PCR. Data manifestasi klinis dan hematologi rutin diperoleh dari penelusuran rekam medis. Penelitian ini merupakan penelitian deskriptif. Sebanyak 75 penderita ikut dalam penelitian. Serotipe virus dapat dideteksi pada $27(36 \%)$ sampel dengan dominasi DENV-3 (13) diikuti DENV-2 (8), DENV-4 (4), dan DENV-1 (2). Kasus DBD ditemukan paling banyak pada infeksi DENV-3. Infeksi DENV-2 memberikan penurunan hemoglobin tertinggi, persentase peningkatan hematokrit tertinggi, leukosit terendah, dan trombosit terendah dibandingkan dengan serotipe lainnya. Kesimpulan penelitian ini adalah ditemukan keempat serotipe di RS Dr. Hasan Sadikin Bandung yang didominasi serotipe DENV-3. Kasus DBD terutama disebabkan DENV-3. Hasil hematologi rutin paling abnormal ditemukan pada infeksi DENV-2. [MKB. 2012;44(4):253-60]
\end{abstract}

Kata kunci: DBD, DD, hematologi rutin, serotipe dengue, SSD

\section{Dengue Virus Serotyping and Its Clinical Manifestation and Routine Haematology in Dengue Infections}

\begin{abstract}
All DENV serotypes can cause a spectrum of disease from dengue fever (DF) to dengue hemorrhagic fever (DHF) and dengue shock syndrome (DSS). It is difficult to differentiate clinical characteristicand hematologic result for each serotype. Aim of this study were to determine dengue serotype and describe clinical manifestation of DF, DHF, DSS and routine hematologic results, i.e.haemoglobin, hematocrit, leukocyte, and thrombocyte in each serotype. This study was conducted at Dr. Hasan Sadikin Hospital Bandung from March 2010 until July 2011. Subjects were dengue patients aged $>14$ years with a history of fever $<5$ days. Blood samples were taken for serotype determination by reverse transcription polymerase chain reaction (RT-PCR) followed by semi-nested PCR. Clinical manifestation data and haematologic result were obtained from medical records. This was a descriptive study. Seventy five patients were included in this study. Dengue serotype can be detected in 27 (36\%) samples with DENV-3 (13) were dominating followed by DENV-2 (8), DENV-4 (4), and DENV-1 (2). DHF was mainly found in DENV-3. DENV-2 gavethe highest decrease in hemoglobin, highest percentage increase in haematocrit, lowest leukocyte, and lowest thrombocyte. In conclusion, all 4 serotypes are found in RSUP Dr. Hasan Sadikin Hospital Bandung with DENV-3 domination. DHF is mainly caused by DENV-3. In routine hematology, the most abnormal results are found in DENV-2 infection. [MKB. 2012;44(4):253-60].
\end{abstract}

Key words: Dengue serotype, DF, DHF, DSS, routine haematology

Korespondensi: Basti Andriyoko, dr., Sp.PK, Departemne Patologi Klinik Fakultas Kedokteran Universitas Padjadjaran Rumah Sakit Dr. Hasan Sadikin, jalan Pasteur 38 Bandung, mobile 0812149433, e-mail basti_dr@yahoo.co.id 


\section{Pendahuluan}

Virus dengue merupakan virus ribonucleic acid (RNA) arbovirus yang menyebabkan infeksi dengan berbagai manifestasi klinis, mulai dari demam dengue (DD), demam berdarah dengue (DBD), sampai dengan sindrom syok dengue (SSD). Virus dengue termasuk dalam famili Flaviviridae dan genus Flavivirus yang terdiri atas empat serotipe, yaitu DENV-1, DENV-2, DENV-3, dan DENV-4. ${ }^{1}$

Indonesia merupakan negara paling besar di Asia Tenggara dan hampir seluruh wilayahnya merupakan daerah endemis untuk infeksi virus dengue. Empat serotipe virus dengue ditemukan bersirkulasi di seluruh Indonesia. Penelitian yang dilakukan pada beberapa daerah di Indonesia pada tahun 1973-2010 hampir selalu menunjukkan dominasi serotipe DENV-3. Dominasi serotipe lainnya yaitu DENV-1 ditemukan di Manado tahun 1974 dan DENV-2 di Bandung tahun 2001. ${ }^{2}$

Setiap infeksi karena serotipe virus dengue dapat menyebabkan manifestasi klinis dan profil epidemiologi yang bervariasi, sehingga sangat sulit untuk menilai karakteristik klinis dan hasil laboratorium yang khas untuk setiap serotipe. Beberapa laporan menyatakan bahwa DENV-2 dan DENV-3 menyebabkan manifestasi klinis yang lebih berat dibandingkan dengan serotipe lainnya. Manifestasi klinis yang lebih ringan disebabkan karena DENV-4. ${ }^{3-6}$

Serotipe virus dengue di suatu daerah selalu mengalami perubahan, dengan demikian sangat diperlukan surveilans kontinu terhadap serotipe virus dengue untuk memahami epidemiologi dan juga memprediksi manifestasi klinis infeksi karena virus dengue termasuk hasil pemeriksaan hematologi rutin untuk melihat kecenderungan infeksi berat akibat infeksi serotipe virus dengue tertentu. Penentuan serotipe virus dengue penting untuk epidemiologi dan juga menentukan potensi patogenitas penyakit tersebut terhadap populasi. Penelitian terbaru untuk menentukan serotipe virus dengue yang bersirkulasi di setiap daerah perlu dilakukan untuk melihat potensi patogenitas virus dengue di daerah dan waktu tersebut. 7,8

Data rawat inap penderita infeksi virus dengue di RS Dr. Hasan Sadikin Bandung pada dua tahun terakhir, tahun 2008 dan 2009 menunjukkan peningkatan yaitu 1.435 kasus pada tahun 2008 menjadi 2.694 kasus pada tahun 2009 dengan jumlah penderita dewasa lebih banyak dibandingkan dengan anak setiap tahunnya. ${ }^{9}$ Penelitian di RS Dr. Hasan Sadikin Bandung oleh Setiabudi ${ }^{10}$ tahun 2001 pada penderita dewasa mendapatkan dominasi serotipe DENV-2 (17 kasus), diikuti DENV-1 (11 kasus), DENV-4 (10 kasus), dan paling sedikit DENV-
3 (2 kasus). Hingga kini belum terdapat data terbaru mengenai serotipe virus dengue di RS Dr. Hasan Sadikin Bandung sejak penelitian terakhir tahun 2001. Tujuan penelitian ini untuk menentukan serotipe virus dengue dan gambaran manifestasi klinis DD, DBD, SSD, serta hasil pemeriksaan hematologi rutin kadar hemoglobin, nilai hematokrit, jumlah leukosit, dan jumlah trombosit setiap serotipe virus dengue.

\section{Metode}

Subjek penelitian ini adalah penderita usia $\geq 14$ tahun yang datang berobat ke Instalasi Gawat Darurat RS Dr. Hasan Sadikin Bandung dengan gejala dan tanda infeksi virus dengue dan telah didiagnosis berdasarkan kriteria WHO, serta bersedia ikut penelitian setelah menandatangani persetujuan (informed consent). Kriteria inklusi penelitian yaitu penderita dengan tanda dan gejala infeksi virus dengue yang telah didiagnosis oleh klinisi berdasarkan kriteria WHO dengan lama demam $\leq 5$ hari. Kriteria eksklusi penelitian yaitu penderita infeksi virus dengue yang tidak dapat ditelusuri hasil pemeriksaan laboratorium hematologi rutin, meliputi kadar hemoglobin, hematokrit, serta jumlah leukosit dan trombosit.

Bahan penelitian yaitu darah penderita infeksi virus dengue yang diambil pada hari pertama penderita datang ke rumah sakit yang diproses menjadi ethylene diamine tetra acid (EDTA) plasma. Bahan penelitian EDTA plasma kemudian dikumpulkan dan disimpan pada suhu $-80{ }^{\circ} \mathrm{C}$ sampai waktu pemeriksaan reverse transcription polymerase chain reaction (RTPCR) dengue. Data rekam medis setiap penderita ditelusuri untuk mendapatkan diagnosis akhir, hasil pemeriksaan serologis IgM dan IgG dengue, serta hasil pemeriksaan laboratorium hematologi kadar hemoglobin, dan hematokrit, serta jumlah leukosit dan trombosit.

Pemeriksaan untuk identifikasi serotipe virus dengue menggunakan metode RT-PCR yang dilanjutkan dengan seminested-PCR. Penelitian ini dilaksanakan di Laboratorium Departemen Patologi Klinik Fakultas Kedokteran Universitas Padjadjaran/RS Dr. Hasan Sadikin Bandung periode Maret 2010-Juli 2011. Penelitian ini adalah penelitian deskriptif dengan jumlah sampel penelitian bergantung pada jumlah penderita yang memenuhi kriteria inklusi. Analisis statistik uji $\chi^{2}$ dilakukan untuk membandingkan frekuensi antar kelompok.

\section{Hasil}

Selama penelitian telah dilakukan pemeriksaan 
Basti Andriyoko: Penentuan Serotipe Virus Dengue dan Gambaran Manifestasi Klinis serta Hematologi Rutin

Tabel 1 Persentase Positivitas RT-PCR Dengue berdasarkan Waktu Pengambilan Sampel

\begin{tabular}{ccccc}
\hline $\begin{array}{c}\text { Waktu Pengambilan } \\
\text { Sampel (Hari ke-) }\end{array}$ & Jumlah Sampel & $\begin{array}{c}\text { Jumlah Positif } \\
\text { RT-PCR Dengue }\end{array}$ & $\begin{array}{c}\text { Persentase } \\
\text { Sampel Positif }\end{array}$ & p \\
\hline 3 & 13 & 5 & 39 & 0,832 \\
4 & 30 & 11 & 37 & \\
5 & 32 & 11 & 34 & \\
Total & 75 & 27 & & \\
\hline
\end{tabular}

Keterangan tabel: RT-PCR=reverse transcriptase-polymerase chain reaction

RT-PCR terhadap 75 sampel penderita infeksi virus dengue.

Subjek penelitian ini terdiri atas 75 penderita infeksi virus dengue dengan rentang usia 14-59 tahun, median 21 tahun. Infeksi virus dengue terbanyak ditemukan pada kelompok usia 14-24 tahun yaitu 49 (65\%) penderita. Perbandingan antara laki-laki dan perempuan adalah 1:1,7.

Dari 75 subjek penelitian diagnosis akhir DD merupakan kasus yang terbanyak yaitu 43 (57\%) kasus, diikuti oleh DBD dan SSD. Pada penelitian ini infeksi virus dengue sekunder merupakan infeksi terbanyak, yaitu 68 (91\%) dari 75 kasus yang diteliti.

Seluruh pengambilan sampel pada penelitian ini dilakukan antara hari ke-3 sampai dengan hari ke-5 demam.

Pengambilan sampel hari ke-3 memberikan positivitas paling tinggi (39\%) bila dibandingkan dengan hari ke-4 dan ke-5. Pada penelitian ini positivitas RT-PCR dengue menurun dengan bertambahnya hari pengambilan sampel dengan nilai $\mathrm{p}$ untuk perbedaan antara hari ke-3, ke-4, dan ke-5 sebesar 0,832 (Tabel 1).

Penelitian ini mendapatkan positivitas RTPCR dengue pada infeksi sekunder lebih rendah bila dibandingkan dengan infeksi primer. Pada tujuh sampel kasus infeksi primer hasil positif ditemukan hanya pada tiga sampel, sedangkan dari 68 sampel pada infeksi sekunder hasil positif sebanyak 24 sampel.

Dari 75 spesimen yang diuji menggunakan RT-PCR dengue, diperoleh 27 (36\%) spesimen yang terdeteksi jenis serotipe virusnya. Serotipe virus dengue yang diperoleh pada penelitian ini adalah DENV-3=13 (13/27), disusul DENV-2=8 $(8 / 27)$, DENV-4=4 (4/27), dan paling sedikit adalah DENV-1=2 (2/27) (Tabel 2).

Serotipe DENV-3 menyebabkan manifestasi klinis pada semua DD (7 kasus) dan DBD (6 kasus). Pada penelitian ini tidak terdapat kasus SSD yang berhasil dideteksi serotipenya (Tabel 2).

Nilai hemoglobin, hematokrit, serta jumlah leukosit dan trombosit rata-rata dihitung pada 26 penderita. Satu penderita tidak diikutsertakan dalam penghitungan karena menderita penyakit penyerta lainnya sehingga memengaruhi kadar hemoglobin, hematokrit, serta jumlah leukosit dan trombosit.

Pada penelitian ini DENV-1 menunjukkan penurunan kadar hemoglobin rata-rata tertinggi $(2,2 \mathrm{~g} / \mathrm{dL})$, peningkatan hematokrit rata-rata tertinggi $(20,1 \%)$, jumlah leukosit rata-rata terendah $\left(1.640 / \mathrm{mm}^{3}\right)$, dan jumlah trombosit ratarata terendah $\left(14.500 / \mathrm{mm}^{3}\right)$ dibandingkan dengan serotipe lainnya.

Sebaran hasil pemeriksaan hematologi rutin pada setiap penderita menunjukkan persentase peningkatan nilai hematokrit tertinggi, penurunan kadar hemoglobin tertinggi, serta jumlah leukosit terendah pada kelompok serotipe DENV-2, sedangkan jumlah trombosit terendah ditemukan pada kelompok serotipe DENV-2 dan DENV-3. Berdasarkan hasil pemeriksaan hematologi rutin rerata, hasil penurunan kadar hemoglobin rerata tertinggi, persentase peningkatan nilai hematokrit tertinggi, dan jumlah leukosit terendah terdapat pada kelompok DENV-1.

Tabel 2 Manifestasi Klinis berdasarkan Serotipe Virus Dengue

\begin{tabular}{lccccc}
\hline $\begin{array}{c}\text { Manifestasi } \\
\text { Klinis }\end{array}$ & $\begin{array}{c}\text { DENV-1 } \\
\mathbf{n}\end{array}$ & $\begin{array}{c}\text { DENV-2 } \\
\mathbf{n}\end{array}$ & $\begin{array}{c}\text { DENV-3 } \\
\mathbf{n}\end{array}$ & $\begin{array}{c}\text { DENV-4 } \\
\mathbf{n}\end{array}$ & Total \\
\hline DD & 2 & 5 & 7 & 1 & 15 \\
DBD & 0 & 3 & 6 & 3 & 12 \\
SSD & 0 & 0 & 0 & 0 & 0 \\
\hline
\end{tabular}

Keterangan: $\mathrm{DENV}=$ dengue virus, $\mathrm{DD}=$ demam dengue, $\mathrm{DBD}=$ demam berdarah dengue, $\mathrm{SSD}=$ sindrom syok dengue 


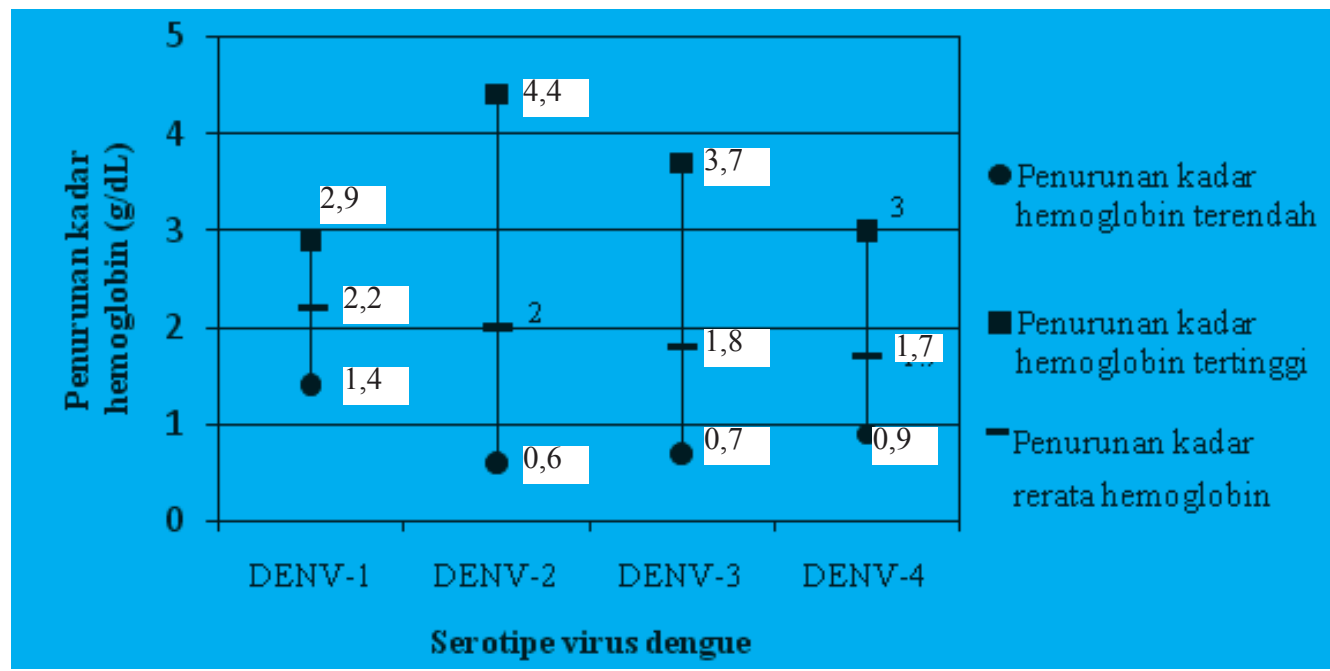

\section{Gambar 1 Penurunan Kadar Hemoglobin berdasarkan Serotipe Virus Dengue}

Keterangan: DENV=dengue virus

\section{Pembahasan}

Pada penelitian ini jumlah penderita infeksi virus dengue terbanyak terdapat pada kelompok usia 14-24 tahun yaitu $49(65 \%)$ kasus diikuti oleh kelompok usia 25-35 tahun sebanyak 15 (20\%) kasus. Hasil serupa juga didapatkan pada penelitian oleh Setiabudi ${ }^{10}$ tahun 2001 di RS Dr. Hasan Sadikin Bandung yang mendapatkan infeksi virus dengue terbanyak terdapat pada kelompok usia 14-29 tahun (64,8\%). Penelitian yang dilakukan di Bangladesh saat epidemi dengue tahun 2000 mendapatkan hasil yang serupa pula, yaitu dari 82 kasus infeksi virus dengue di rumah sakit terjadi pada orang dewasa dengan kasus tertinggi pada rentang usia 18-33 tahun. ${ }^{1}$

Infeksi virus dengue lebih banyak ditemukan pada dewasa bila dibandingkan dengan anak. Hal tersebut juga terlihat pada data rekam medis rawat inap RS Dr. Hasan Sadikin Bandung tahun 20072009 yang menunjukkan infeksi virus dengue pada orang dewasa yang menjalani rawat inap lebih banyak dibandingkan dengan anak. ${ }^{9}$ Surveilans yang dilakukan di Jakarta tahun 1975-1984 telah menunjukkan peningkatan insidensi infeksi virus

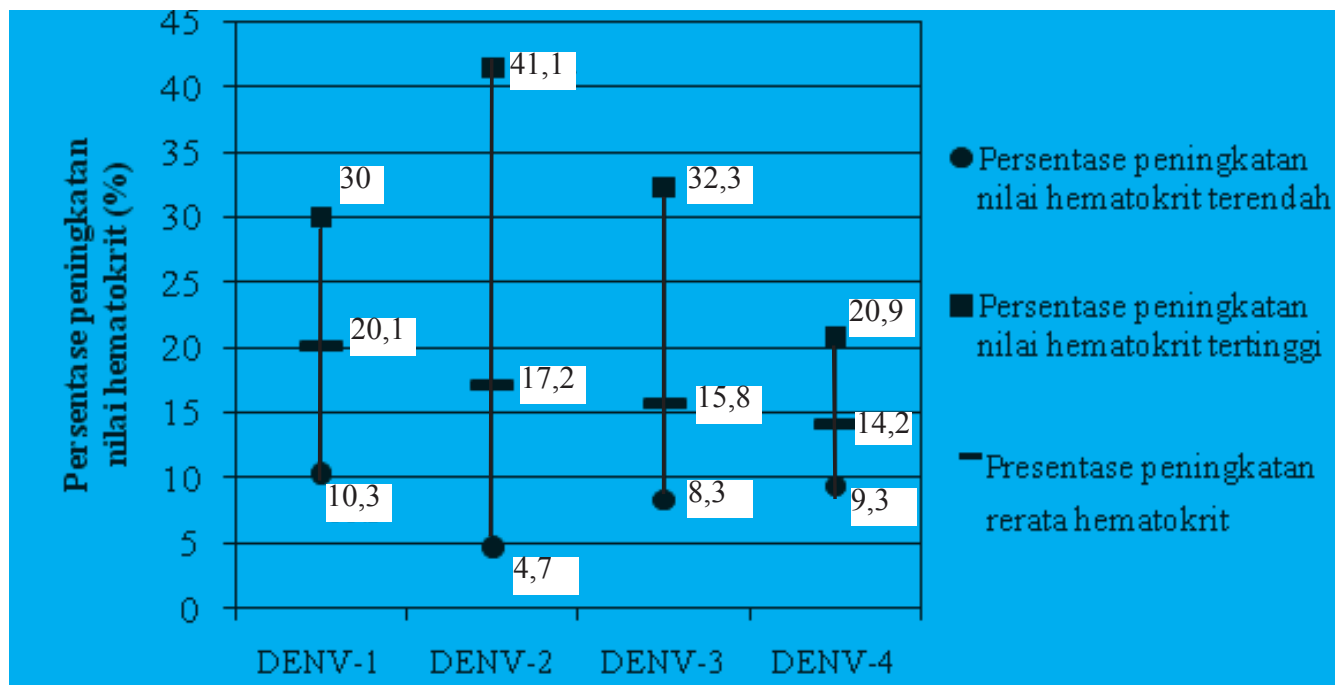

Gambar 2 Persentase Peningkatan Nilai Hematokrit berdasarkan Serotipe Virus Dengue Keterangan: $\mathrm{DENV}=$ dengue virus 
Basti Andriyoko: Penentuan Serotipe Virus Dengue dan Gambaran Manifestasi Klinis serta Hematologi Rutin

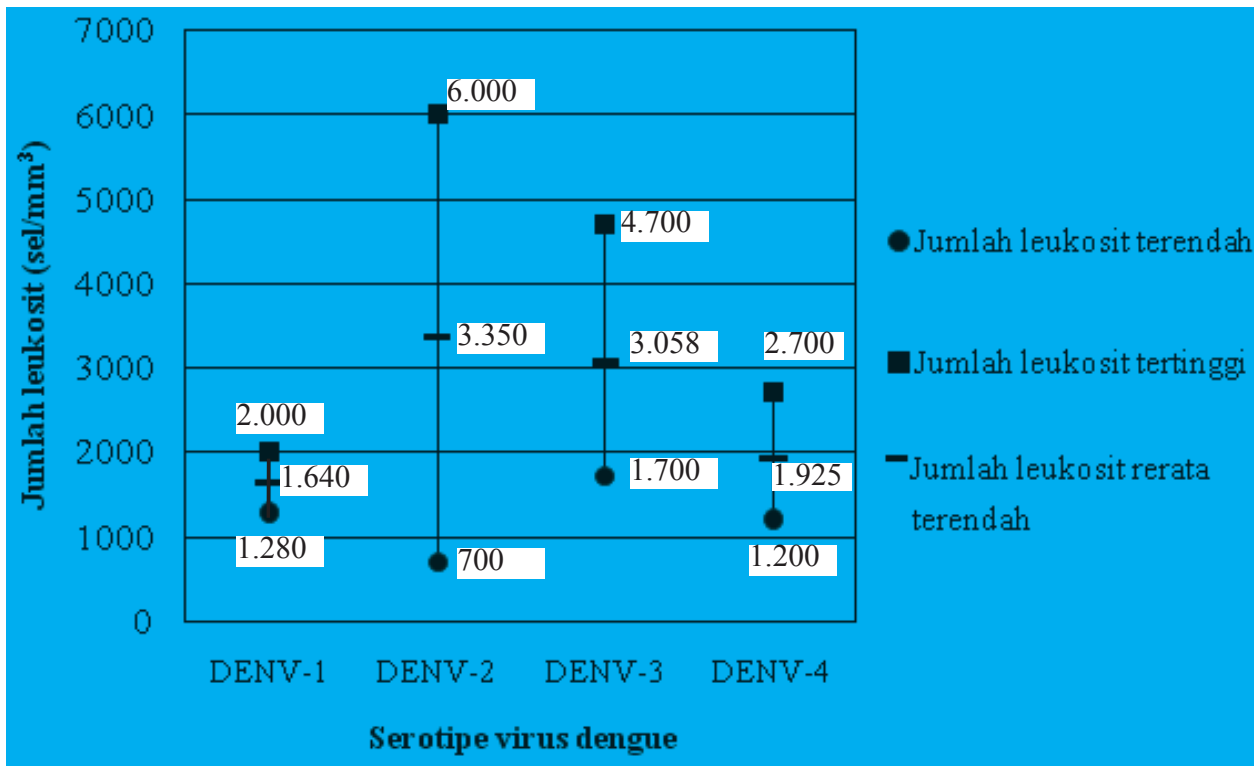

\section{Gambar 3 Hasil Pemeriksaan Jumlah Leukosit berdasarkan Serotipe Virus Dengue Keterangan: DENV=dengue virus}

dengue pada usia dewasa muda. ${ }^{1}$ Penelitian di Thailand tahun 2004-2005 oleh Hanafusa dkk. ${ }^{11}$ juga memperoleh hasil yang serupa yaitu jumlah penderita infeksi virus dengue pada dewasa lebih banyak dibandingkan dengan anak dengan usia rerata 17,6 tahun. Data infeksi virus dengue di Singapura tahun 2000 menunjukkan lebih dari
$70 \%$ kasus terjadi pada usia 25 tahun ke atas. Hal tersebut merupakan kebalikan dari tahun 1970 yang hanya mendapatkan sekitar 30\% kasus pada usia 25 tahun ke atas. ${ }^{12}$

Pergeseran usia pada infeksi virus dengue antara lain dapat disebabkan karena perubahan tempat transmisinya virus dengue. Keadaan ini

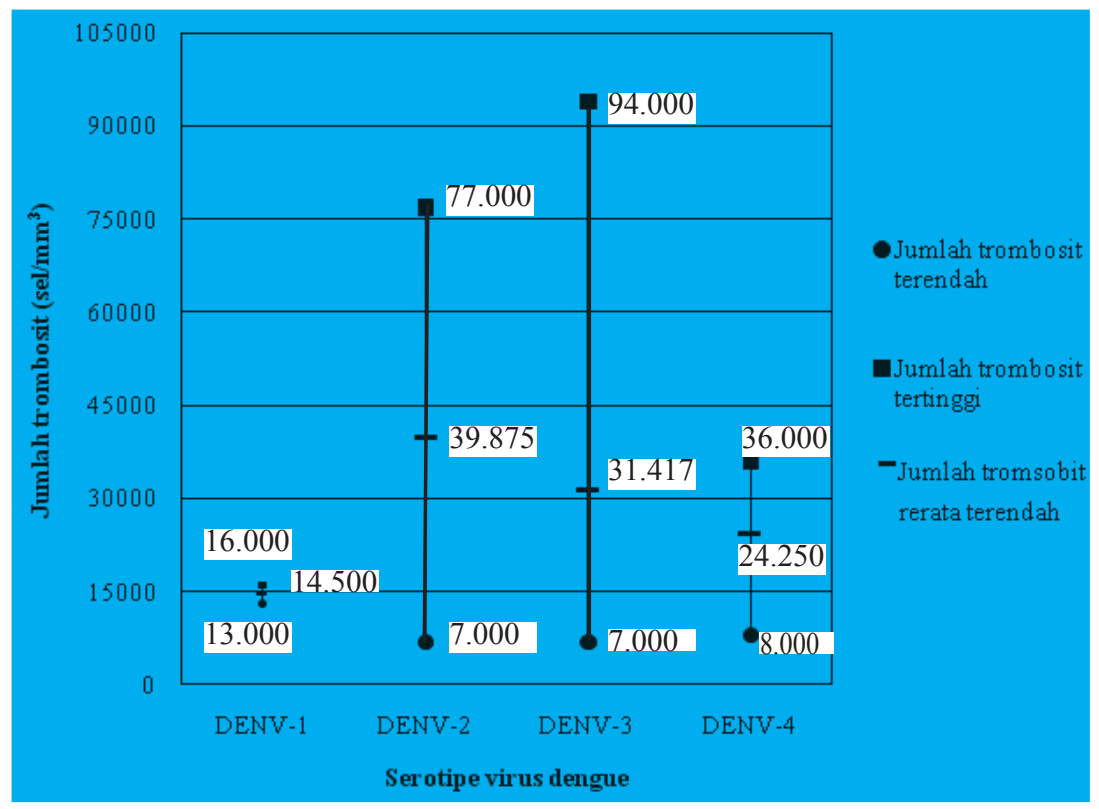

Gambar 4 Hasil Pemeriksaan Jumlah Trombosit berdasarkan Serotipe Virus Dengue Keterangan: $\mathrm{DENV}=$ dengue virus 
dibuktikan dengan penelitian oleh Ooi dkk. ${ }^{13}$ di Singapura Patumanond dkk. ${ }^{14}$ di Thailand yang menunjukkan perubahan tempat transmisi virus dengue dari perumahan ke sekolah, tempat kerja, atau tempat umum sejalan dengan keberhasilan program pengendalian vektor di perumahan.

Persentase positivitas hasil RT-PCR dengue menurun dengan semakin bertambahnya hari pengambilan dari hari pertama demam. Hal ini sesuai dengan penelitian sebelumnya yang mendapatkan semakin lama waktu pengambilan sampel dari awal onset penyakit maka persentase hasil pemeriksaan positif juga akan berkurang, ${ }^{15}$ namun pada penelitian ini tidak didapatkan perbedaan yang bermakna antara pengambilan hari ke-3, ke-4, dan ke-5 ( $\mathrm{p}=0,832)$.

Serotipe virus dengue dapat dideteksi pada 27 (36\%) sampel penderita, hal ini serupa dengan penelitian sebelumnya oleh Setiabudi ${ }^{10}$ di RS Dr. Hasan Sadikin Bandung tahun 2001 yang berhasil mendeteksi sebanyak $39(35,1 \%)$ dari 111 spesimen yang diperiksa RT-PCR dengue dengan satu spesimen di antaranya terdeteksi memiliki 2 serotipe yaitu DENV-2 dan DENV-4. Pada penelitian ini tidak ditemukan satu spesimen yang memiliki 2 serotipe secara bersamaan. Hasil positivitas RT-PCR dengue yang rendah pada penelitian ini dapat disebabkan rendahnya viral load pada penderita yang diteliti karena $91 \%$ kasus merupakan infeksi dengue sekunder dengan waktu viremia yang lebih singkat dibandingkan dengan infeksi dengue primer. Riswari dkk. ${ }^{16}$ di Jakarta dan Bandung mendapatkan waktu viremia yang lebih singkat pada infeksi dengue sekunder $(2,9 \pm 1,9$ hari) dibandingkan dengan infeksi primer $(4,3 \pm 2$ hari).

Penelitian ini mendapatkan dominasi serotipe virus dengue oleh DENV-3 (13 kasus) diikuti oleh DENV-2 (8 kasus), DENV-4 (4 kasus), dan DENV-1 (2 kasus). Hasil ini berbeda dengan hasil RT-PCR dengue pada penelitian Setiabudi ${ }^{10}$ di RS Dr. Hasan Sadikin Bandung tahun 2001 yang mendapatkan DENV-2 serotipe terbanyak (17 kasus), diikuti DENV-1 (11 kasus), DENV-4 (10 kasus), dan paling sedikit adalah DENV-3 (2 kasus).

Empat serotipe virus dengue telah ditemukan bersirkulasi di Indonesia. Penelitian yang telah dilakukan di beberapa daerah di Indonesia tahun 1973-2010 hampir selalu menunjukkan dominasi serotipe DENV-3. Dominasi serotipe lainnya yaitu DENV-1 ditemukan di Manado tahun 1974 dan DENV-2 di Bandung tahun 2001.2

Penelitian di 5 rumah sakit yang terdapat di Jawa Barat tahun 2010 oleh Ipa dan Astuti ${ }^{17}$ pada 46 penderita infeksi virus dengue mendapatkan pola serotipe yang mirip dengan penelitian ini yaitu dominasi DENV-3 sebanyak 27 kasus diikuti DENV-2 sebanyak 14 kasus, sedangkan DENV-1 dan DENV-4 masing-masing 3 kasus. Pada penelitian tersebut didapatkan 1 kasus concurrent infections DENV-3 dan DENV-4. Penelitian epidemiologi dan klinis di Indonesia telah menunjukkan perbedaan strain atau subtipe pada serotipe DENV-3 berperan pada transmisi dan beratnya penyakit infeksi virus dengue di Indonesia..$^{18}$

Penelitian ini mendapatkan kasus DBD lebih banyak ditemukan pada infeksi oleh DENV-3 (6 kasus) diikuti oleh DENV-2 (3 kasus) dan DENV4 (3 kasus). Hasil ini sesuai dengan penelitian sebelumnya oleh Kumaria di India tahun 20022006, dan Chan dkk. ${ }^{4}$ di Taiwan tahun 19982007 bahwa infeksi DENV-3 menyebabkan manifestasi klinis yang lebih berat dibandingkan dengan serotipe lainnya. Penelitian di Jawa Barat tahun 2010 juga mendapatkan hasil yang sama dengan penelitian ini, yaitu DBD paling banyak disebabkan oleh infeksi DENV-3 dan DENV-2. ${ }^{17}$

Pada penelitian ini, DENV-1 memberikan hasil pemeriksaan hematologi rata-rata paling abnormal untuk semua parameter dibandingkan dengan serotipe lainnya. Hal ini dapat disebabkan karena jumlah sampel dengan hasil DENV-1 terlalu sedikit yaitu 2 sampel. Penurunan kadar hemoglobin tertinggi, persentase peningkatan nilai hematokrit tertinggi, dan jumlah trombosit terendah ditemukan pada kelompok serotipe DENV-2 diikuti oleh DENV-3, sedangkan jumlah leukosit terendah terdapat pada DENV-2 diikuti oleh DENV-4, dan DENV-3. Hal tersebut serupa dengan penelitian sebelumnya yang menunjukkan DENV-2 dan DENV-3 memiliki potensi untuk menimbulkan manifestasi klinis yang lebih berat dibandingkan dengan serotipe lainnya. ${ }^{3-5}$

Serotipe DENV-2 dan DENV-3 yang berasal dari Asia telah dihubungkan dengan kejadian epidemi dan infeksi dengue berat. Genotipe dari subtipe Asia serotipe DENV-2 dan DENV-3 juga telah menyebabkan siklus endemis di benua lain dan pada beberapa kasus telah menggantikan genotipe lain yang tidak menyebabkan infeksi dengue berat. Penelitian yang dilakukan akhirakhir ini mendapatkan sel target primer (sel dendrit) manusia dan pada nyamuk, serotipe DENV-2 dan DENV-3 menghasilkan titer virus yang lebih tinggi dibandingkan dengan serotipe lainnya. Sampai saat ini belum dapat dipahami mengapa pada beberapa serotipe virus dengue mempunyai kemampuan replikasi yang lebih tinggi bila dibandingkan dengan serotipe lainnya, sehingga perlu dilakukan pengawasan terhadap transmisi serotipe virus dengue yang memiliki potensi virulensi tinggi untuk menentukan apakah virulensi juga dipengaruhi oleh faktor genetik pejamu dan status imun pejamu sebelumnya. ${ }^{6}$ 
Hasil hematologi rutin pada penelitian ini serupa dengan penelitian yang dilakukan oleh Kalayanarooj dan Nimmannitya ${ }^{19}$ di Thailand pada tahun 1995 sampai dengan tahun 1999 terhadap 2.398 penderita infeksi dengue, yaitu peningkatan nilai hematokrit tertinggi dan jumlah trombosit paling rendah ditemukan pada infeksi DENV-2. Penurunan kadar hemoglobin tertinggi pada penelitian ini juga disebabkan oleh DENV-2, hal ini sesuai dengan penelitian oleh Balmaseda dkk. $^{3}$ di Nikaragua pada tahun 1999-2001 dan Kumaria $^{5}$ di India pada tahun 2002-2006 yang mendapatkan manifestasi perdarahan terutama lebih sering ditemukan pada infeksi DENV-2.

Keterbatasan penelitian yaitu jumlah sampel sedikit akibat terbatasnya waktu penelitian dan rendahnya positivitas RT-PCR dengue yang kemungkinan dapat disebabkan karena kejadian infeksi virus dengue sekunder yang lebih banyak daripada infeksi virus dengue primer pada sampel penderita yang diperiksa sehingga waktu viremia lebih singkat.

Simpulan, ditemukan keempat serotipe virus dengue tersebut dan serotipe terbanyak yang ditemukan DENV-3. Infeksi oleh serotipe DENV3 menyebabkan kasus DD dan DBD terbanyak dibandingkan dengan serotipe lainnya. Infeksi oleh serotipe DENV-2 memberikan gambaran hasil penurunan kadar hemoglobin tertinggi, persentase peningkatan nilai hematokrit tertinggi, dan jumlah trombosit terendah dibandingkan dengan serotipe lainnya.

\section{Daftar Pustaka}

1. Guha-Sapir D, Schimmer B. Dengue fever: new paradigms for a changing epidemiology. Emerg Themes Epidemiol. 2005;2(1):1-10.

2. Setiati TE, Wagenaar JFP, de Kruif MD, Mairuhu ATA, van Gorp ECM, Soemantri A. Changing epidemiology of dengue haemorrhagic fever in Indonesia. Dengue Bull. 2006;30:1-14.

3. Balmaseda A, Hammond SN, Perez L, Tellez Y, Saborio SI, Mercado JC, dkk. Serotypespecific differences in clinical manifestations of dengue. Am J Trop Med Hyg. 2006;74(3): $449-56$.

4. Tsai JJ, Chan KS, Chang JS, Chang K, Lin $\mathrm{CC}$, Huang JH, dkk. Effect of serotypes on clinical manifestations of dengue fever in adults. J Microbiol Immunol Infect. 2009;42(6):471-8.

5. Kumaria R. Correlation of disease spectrum among four Dengue serotypes: a five years hospital based study from India. Braz J Infect Dis. 2010;14(2):141-6.
6. Simmons CP, Halstead SB, Rothman A, Harris E, Screaton G, Rico-Hesse R, dkk. Report of the scientific working group on dengue. Geneva, Switzerland: World Health Organization; 2006.

7. Domingo $C$, Palacios $G$, Niedrig $M$, Cabrerizo M, Jabado O, Reyes N, dkk. A new tool for the diagnosis and molecular surveillance of dengue infections in clinical samples. Dengue Bull. 2004;28:87-95.

8. World Health Organization. Dengue: guidelines for diagnosis, treatment, prevention and control. France: WHO; 2009.

9. Bagian Rekam Medis. Jumlah pasien rawat inap Rumah Sakit Dr. Hasan Sadikin Bandung. Rumah Sakit Umum Pusat Dr. Hasan Sadikin Bandung; 2010.

10. Setiabudi E. Manifestasi klinik dan serotipe virus pada penderita tersangka demam berdarah dengue [tesis]. Bandung: Universitas Padjadjaran; 2002.

11. Hanafusa S, Chanyasanha C, Sujirarat D, Khuankhunsathid I, Yaguchi A, Suzuki T. Clinical features and differences between child and adult dengue infections in Rayong Province, southeast Thailand. Southeast Asian J Trop Med Public Health. 2008;39(2):252-9.

12. Ooi EE. Changing pattern of dengue transmission in Singapore. Dengue Bull. 2001;25:40-4.

13. Ooi EE, Hart TJ, Tan HC, Chan SH. Dengue seroepidemiology in Singapore. Lancet. 2001;357(9257):685-6.

14. Patumanond J, Tawichasri C, Nopparat S. Dengue hemorrhagic fever, Uttaradit, Thailand. Emerg InfectDis.2003;9(10):134850.

15. Guilarde AO, Turchi MD, Sigueira JB Jr, Feres VC, Rocha B, Levi JE, dkk. Dengue and dengue hemorrhagic fever among adults: clinical outcomes related to viremia, serotypes, and antibody response. J Infect Dis. 2008;197(6):817-24.

16. Riswari SF, Alisjahbana B, Velies DS, Widjaja S, Kosasih H, Laura, dkk. Analysis of fever, viremia, and antibody kinetics in dengue cases. MKB. 2010;42(4S):22S.

17. Ipa M, Astuti EP. Secondary infection and Den-3 serotype most common among dengue patients: a preliminary study. Health Science Indones. 2010;1(1):14-9.

18. Dewi BE, Takasaki T, Tajima S, Sudiro TM, Larasati RP, Corwin AL, dkk. Genotypic and phenotypic characteristics of DENV3 isolated from patients with different disease severities in Indonesia. Dengue Bull. 2009;33:45-59. 
Basti Andriyoko: Penentuan Serotipe Virus Dengue dan Gambaran Manifestasi Klinis serta Hematologi Rutin

19. Kalayanarooj S, Nimmannitya S. Clinical and laboratory presentations of dengue patients with different serotypes. Dengue Bull. 2000;24:53-9. 